\title{
Two sequestrate cortinarioid fungi from Rio Grande do Sul, Brazil
}

\author{
Vagner G. Cortez ${ }^{1,3}$, Iuri G. Baseia ${ }^{1}$, Rosa T. Guerrero ${ }^{1}$ and Rosa Mara B. da Silveira ${ }^{1}$
}

Received: 10.04.2008; accepted: 09.10.2008

ABSTRACT - (Two sequestrate cortinarioid fungi from Rio Grande do Sul, Brazil). Descomyces albellus (Massee \& Rodway) Bougher \& Castellano and Setchelliogaster tenuipes (Setch.) Pouzar, two sequestrate fungi of the Cortinariaceae are reported from Rio Grande do Sul State, in southern Brazil. The distribution and taxonomy of both taxa are briefly discussed, and descriptions, line drawings, and photos are presented. Setchelliogaster tenuipes is reported for the first time in Rio Grande do Sul State, and the occurrence of D. albellus is confirmed.

Key words: Agaricales, Cortinariales, ectomycorrhizal fungi, Eucalyptus, gasteromycetes

RESUMO - (Dois fungos gasteróides no Rio Grande do Sul, Brasil). Descomyces albellus (Massee \& Rodway) Bougher \& Castellano e Setchelliogaster tenuipes (Setch.) Pouzar, ambos representantes gasteróides da família Cortinariaceae, são registrados para a micobiota sul-rio-grandense. São apresentadas descrições, ilustrações e fotos, bem como uma breve discussão sobre a taxonomia e distribuição geográfica das espécies mencionadas. Setchelliogaster tenuipes é registrada pela primeira vez na micobiota sul-rio-grandense, enquanto a ocorrência de D. albellus é confirmada.

Palavras-chave: Agaricales, Cortinariales, Eucalyptus, fungos ectomicorrízicos, gasteromicetos

\section{Introduction}

For many years, the family Cortinariaceae Heim ex Pouzar comprised several agaric genera such as Cortinarius Fr., Galerina Earle, Gymnopilus (Fr.) Murrill, and Inocybe Fr., among others, following traditional classifications (Pegler 1983, Singer 1986). Morphological and molecular evidence led to the inclusion of several sequestrate (gasteroid and secotioid) genera into the family, for example, Descomyces Bougher \& Castellano, Hymenogaster Vittad., Setchelliogaster Pouzar, and Thaxterogaster Singer. These relationships have been discussed in previous studies (Smith 1973, Thiers 1984, Peintner et al. 2001, Francis \& Bougher 2002, Castellano et al. 2004), and the proposal of a segregated order, Cortinariales Jülich (Jülich 1981), from the Agaricales Underw. has been accepted by several authors (Beaton et al. 1985a, Pegler et al. 1993, Martín \& Moreno 2001). Currently, studies of molecular systematics have provided some insights towards the phylogenetic relationships of this large group (Moncalvo et al. 2002, Matheny et al. 2006), however, the available results have not been conclusive because of its enormous variability.
In southern Brazil, in spite of numerous mycological surveys, there is little information about the occurrence of sequestrate members of Cortinariaceae. Rick (1934, 1961) reported only Hymenogaster vulgaris Tul. \& C. Tul. from Rio Grande do Sul, whose specimens were not available for revision. More recently, Giachini et al . (2000) reported four species of cortinarioid sequestrate fungi associated with Eucalyptus in the state of Santa Catarina: Descomyces albellus (Massee \& Rodway) Bougher \& Castellano, D. albus (Klotzsch) Bougher \& Castellano, D. giachinii Trappe, V.L. Oliveira, Castellano \& Claridge, and Setchelliogaster tenuipes (Setch.) Pouzar.

With the aim to revise the gasteroid mycobiota of Rio Grande do Sul, the authors have collected and studied specimens in the region. As partial results of this survey, we report the occurrence of two interesting sequestrate species of Cortinariaceae associated to Eucalyptus.

\section{Material and methods}

The specimens were collected in Eucalyptus plantations during mycological surveys in Rio Grande

1. Universidade Federal do Rio Grande do Norte, Departamento de Botânica, Ecologia e Zoologia, 59072-970 Natal, RN, Brazil

3. Corresponding author: cortezvg@yahoo.com.br 
do Sul, in southern Brazil. The studied material is preserved in the ICN herbarium (Universidade Federal do Rio Grande do Sul, Instituto de Biociências). Macroscopic and microscopic analyses followed standard methods for the study of gasteroid mushrooms (Miller Junior \& Miller 1988, Castellano et al. 2004). Basidiospore measurements include the complex perisporium. Color codes are those of Kornerup \& Wanscher (1978). Scanning Electron Microscopy (SEM) studies were performed at the Universidade Federal do Rio Grande do Norte with a Phillips scanning electron microscope. For preparation of the samples, the following procedure was adopted: small portions of the gleba were removed, then transferred to aluminum stubs previously covered with a doubleface carbon tape. Later, the stubs were sputter coated with gold for up to five minutes before examination under the SEM, under $20 \mathrm{Kv}$ and magnification of $5,000-6,000 \times$.

\section{Results and Discussion}

Descomyces albellus (Massee \& Rodway) Bougher \& Castellano, Mycologia 85: 282. $1993 \equiv$ Hymenogaster albellus Massee \& Rodway in Massee, Bull. Misc. Inf. 138: 126. 1898.

Figures 1, 3, 5-7

Basidiomes gastroid, partially hypogeous, subglobose to globose in shape, 8-11 mm diam., 6-7 $\mathrm{mm}$ high. Peridium white (KW 1A1) or light yellow (KW 1A4) to dark yellow (KW 4C8), up to $1 \mathrm{~mm}$ thick, smooth and dry or slightly moist when fresh, opening by irregular dehiscence at the top of the basidiomes, rhizomorphs absent or poorly developed. Stipe absent. Columella usually absent or reduced to a basal disc. Gleba loculate, composed by anastomosed lamellae, initially brownish grey (KW 5C2) and then yellowish brown (KW 5E7-5F8) at maturity. Basidiospores (14.2-)17-18.5(-19.5) × (10-)11.5$13.5(-14.5) \mu \mathrm{m}$, ovoid to limoniform in frontal view, ovoid to fusiform in profile, color rusty under $\mathrm{KOH}$, walls very thick and ornamented by sub-reticulate to verrucose perisporium; under SEM the basidiospore surface has a sub-smooth wall with slight reticulation. Basidia (17-)25-34(-38) $\times(6-) 8.5-11(-12.5) \mu \mathrm{m}$, clavate, mainly bisporic, some tetrasporic. Basidioles 24.5-34.5(-47) $\times 8.5-12 \mu \mathrm{m}$, variable in shape, lageniform, subfusoid, ampullaceous, some with a capitate apex, walls hyaline and thin, basal clamp present. Peridium two layered: the external layer formed by non-gelatinized, ascendant to prostrate hyphae, 5-12 $\mu \mathrm{m}$ diam., with thickened, golden yellow walls; the internal layer is composed by filamentous, thin-walled, hyaline hyphae, 6-8.5 $\mu \mathrm{m}$ diam. Clamp connections present in most septa.

Material examined: BRAZIL. Rio Grande do Sul: Santa Maria, Boca do Monte, Estação Experimental de Silvicultura (FEPAGRO), 3-VI-2006, V.G. Cortez 51/06 (ICN); idem, in Eucalyptus plantation, 12-V2007, V.G. Cortez 90/07 (ICN).

Distribution: widespread in Eucalyptus plantations throughout the world (Lago \& Castro 2004). In South America, it is known from Argentina (Wright \& Albertó 2006), Brazil, Chile, and Uruguay (Dodge \& Zeller 1934).

The genus Descomyces was segregated from Hymenogaster because its members present rusty colored basidiospores with a distinct verrucose to subreticulate perisporium and a non-gelatinized peridium that is trichodermial to epithelial (Bougher \& Castellano 1993). Five species are currently recognized in the genus, four of which are associated with Eucalyptus (Francis \& Bougher 2004, Lago $\&$ Castro 2004). The first report of Descomyces in Brazil was from Santa Catarina by Giachini et al. (2000), who reported D. albellus, D. albus (Klotzsch) Bougher \& Castellano, and D. giachinii Trappe, Castellano, Oliveira \& Claridge. All of these species are associated with exotic species of Eucalyptus. Descomyces albellus is closely related to D. albus. The most significant difference between these species is the peridium structure, which is trichodermial in $D$. albellus and epithelial in D. albus (Francis \& Bougher 2004, Lago \& Castro 2004). Dodge \& Zeller (1934) reported a collection of Hymenogaster albellus by Rick from Brazil, without any indication of locality. Since Rick collected over many years in Rio Grande do Sul, it is probable that the material was gathered in this state. In contrast, the specimens studied here confirm the presence of this species in Rio Grande do Sul.

Setchelliogaster tenuipes (Setch.) Pouzar, Ceská Mykol. 12: 34, 1958 इ Secotium tenuipes Setch., J. Mycol. 13: 239. 1907 三Descolea tenuipes (Setch.) Neville \& Poumarat, Bull. Soc. Mycol. Fr. 120: 68. 2004.

Figures 2, 4, 8-10 

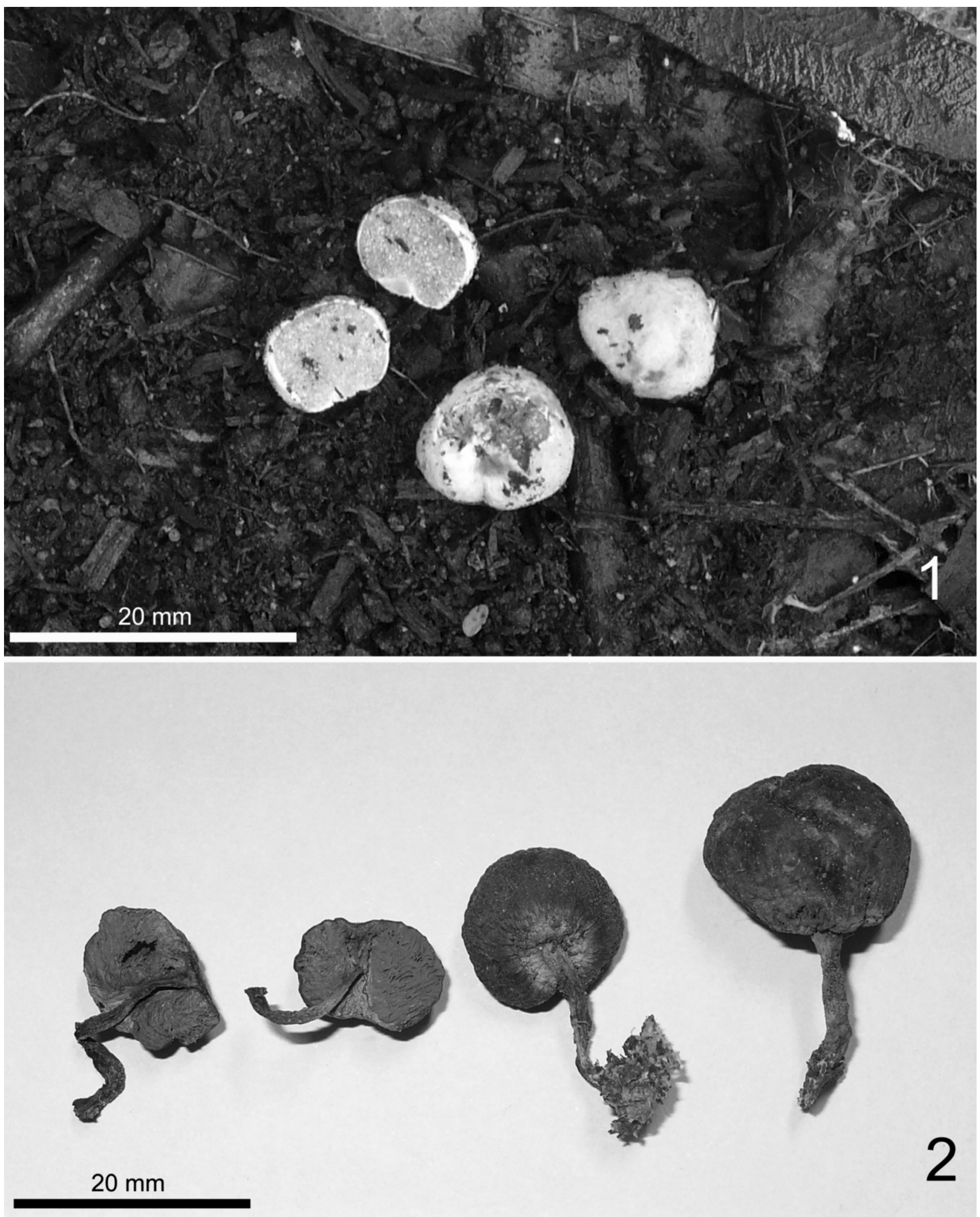

Figures 1-2. Basidiomes of Descomyces and Setchelliogaster. 1. Fresh basidiomes of D. albellus. 2. Dried basidiomes of S. tenuipes. 


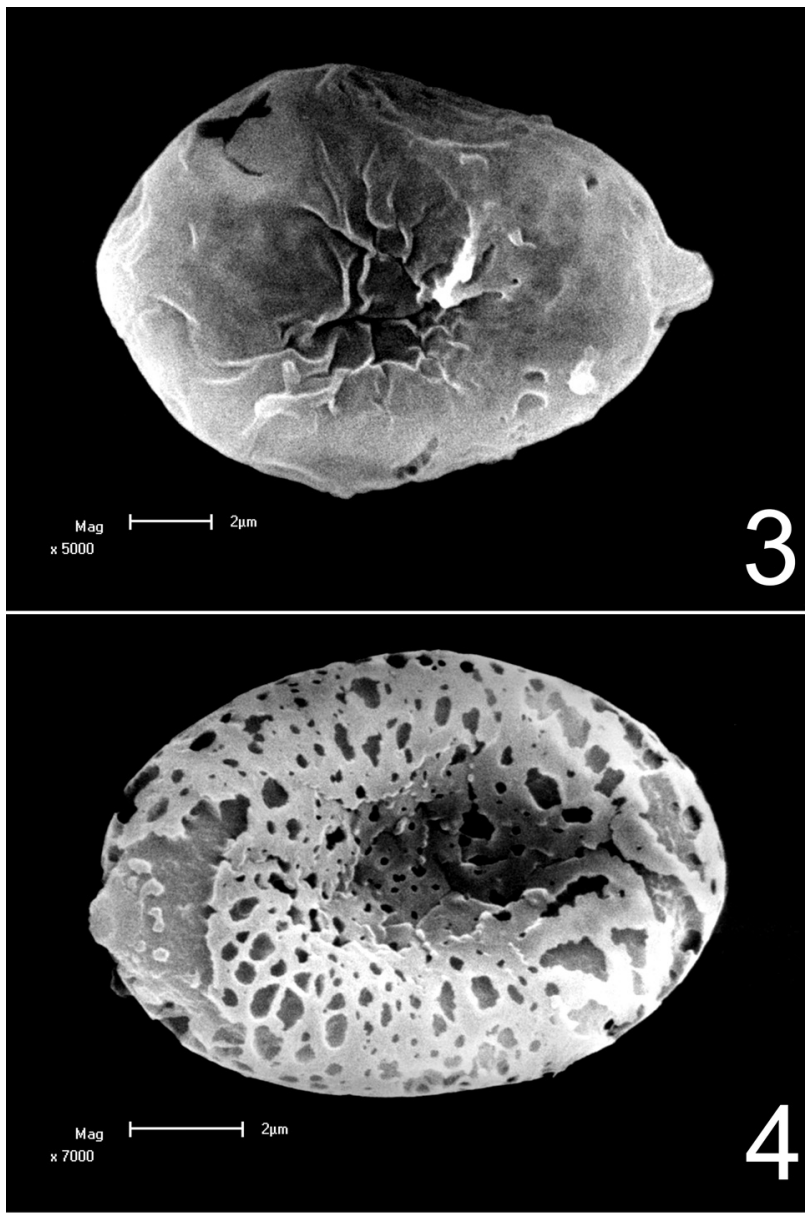

Figures 3-4. Basidiospores under SEM. 3. Descomyces albellus. 4. Setchelliogaster tenuipes.

Basidiomes secotioid, stipitate and with a globose and enclosed pileus, 22-33 mm high. Pileus 13-17 mm diam., 9-14 $\mathrm{mm}$ high, subglobose to globosedepressed. Peridium reddish brown (KW 9E8) to dark brown (KW 9F6), up to $1 \mathrm{~mm}$ thick, surface dry and rugulose to rugose, dehiscence not observed. Stipe 11$19 \times 1.5-3 \mathrm{~mm}$, sinuous or in some cases subcylindrical and erect, with a conspicuous bulbous base, attached to soil and roots by whitish and thin rhizomorphs, color reddish brown (KW 9E8). Columella continuous with the stipe, crossing the entire extension of the gleba. Gleba light brown (KW 6D7), loculate, formed by anastomosed lamellae. Basidiospores (12-)13.5-16(17.2) $\times(8-) 9.2-11(-12.2) \mu \mathrm{m}$, ovoid to ellipsoid in both face and side view, rusty under $\mathrm{KOH}$, with a punctuate and thickened wall, apiculus prominent; under SEM, the perisporium has a perforate to subreticulate pattern.
Basidia 23.5-26 × 6-7.5 $\mu \mathrm{m}$, clavate, hyaline and thinwalled, mainly producing two (less commonly four) basidiospores. Cystidia rare; when present, 17.5-28.5 $\times(10-) 11.5-13.5(-14.5) \mu \mathrm{m}$, hyaline and thin-walled, lecythiform to lageniform, with a distinct capitate, globose apex. Peridium pseudoparenchymatic, composed by subglobose hyphae, 12-24 $\mu \mathrm{m}$ diam., with thin to slightly thickened, yellowish brown walls, over a filamentous layer of yellowish hyphae. Clamp connections present.

Material examined: BRAZIL. Rio GRAnde Do Sul: Guaíba, Estação da CEEE, in Eucalyptus plantation, III-1987, R.T Guerrero s.n. (ICN56595); Viamão, Estação Agronômica UFRGS, in Eucalyptus plantation, 27-VI-1987, E. Esposito (ICN56556).

Distribution: widespread in Eucalyptus plantations throughout the world (Lago \& Castro 2004). It has been reported in South America from Argentina and Uruguay by Wright (1980) and from Chile by Lazo (1972).

The genus Setchelliogaster is currently accepted as comprising five species, two of which are known to be associated with Eucalyptus (Lago \& Castro 2004). The only known report of the genus in Brazil was of $S$. tenuipes from the neighboring state of Santa Catarina (Giachini et al. 2000). The main features of S. tenuipes are the reddish brown basidiomes, the presence of a well-developed stipe, and the lecythiform cystidia (Lago \& Castro 2004). The latter structures are scarce and some authors consider them to be absent (Martín \& Moreno 2001), but as shown and discussed in detail by Lago et al. (2001) they are present only in the partially exposed margin of anastomosed gills. The systematic position of Setchelliogaster is controversial; some authors (Kirk et al. 2001, Moreno et al. 1997) place it within the Bolbitiaceae Singer (due to the epithelial peridium and the Conocybe-like cystidia) whereas others include it in the Cortinariaceae (Beaton et al. 1985b, Castellano et al. 2004). The relationships of Setchelliogaster with Descomyces and Descolea have been discussed by several authors due to the nature of the peridium/pileipellis, shape of cystidia, basidiospore type, and the mycorrhizal status of their species (Bougher \& Castellano 1993, Lago et al. 2001, Lago \& Castro 2004). The material studied here was collected more than twenty years ago, but the report was never published. At that time, part of this material was sent to Dr. Rolf Singer, who identified (in litt.) the specimens as $S$. tenuipes. 

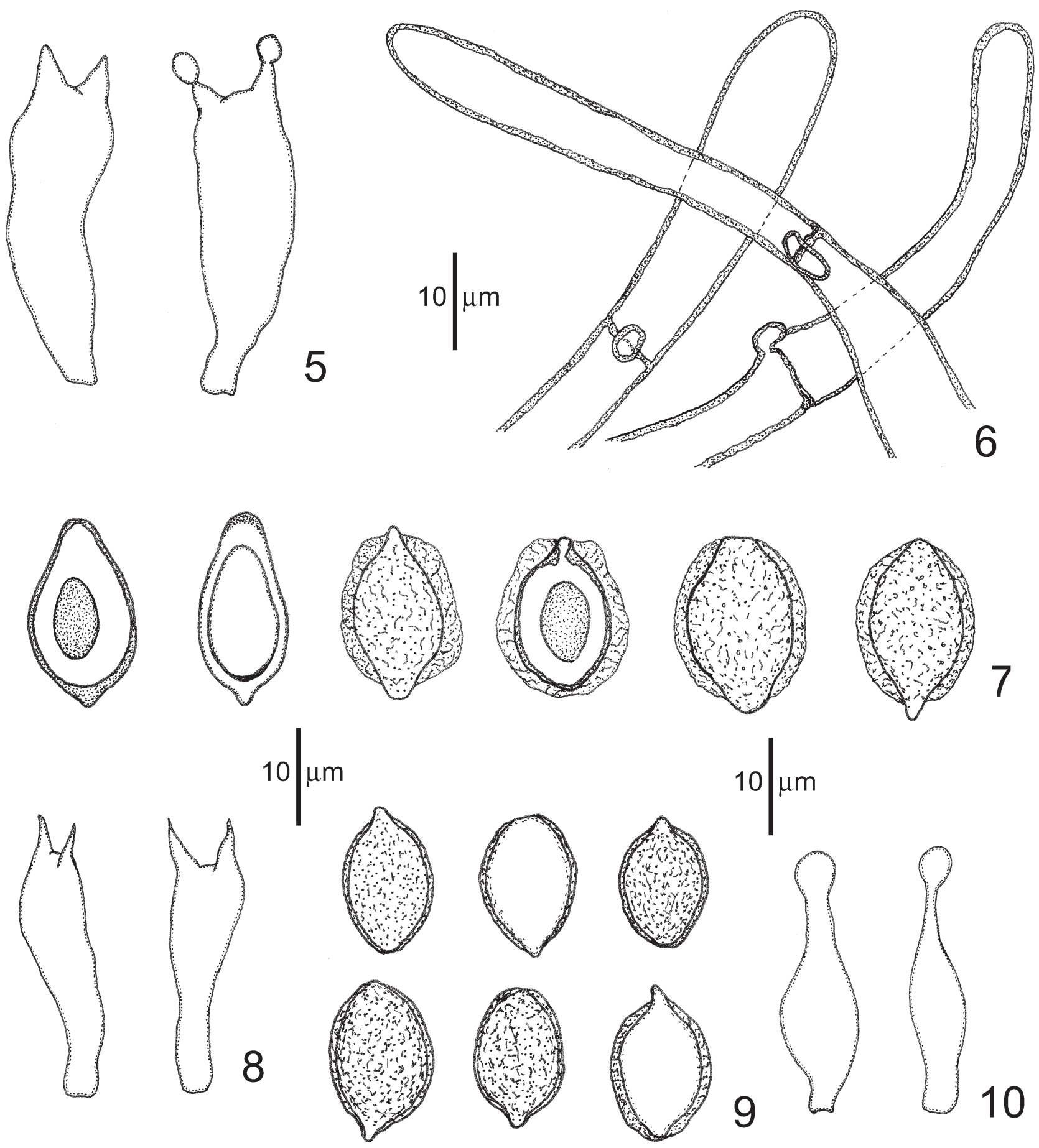

10

Figures 5-10. Details of Descomyces albellus and Setchelliogaster tenuipes. 5-7. D. albellus. 5. Basidia. 6. External hyphae of the peridium. 7. Basidiospores. 8-10. S. tenuipes. 8. Basidia. 9. Basidiospores. 10. Cystidia. 


\section{Acknowledgements}

The authors thank CNPq for financial support. Dr. Nathan Smith and Dr. Maria Alice Neves are acknowledged for English improvements to the final version of the text.

\section{Literature cited}

Beaton, G., Pegler, D.N. \& Young, T.W.K. 1985a. Gasteroid Basidiomycota of Victoria State, Australia. 3. Cortinariales. Kew Bulletin 40: 167-204.

Beaton, G., Pegler, D.N. \& Young, T.W.K. 1985 b. Gasteroid Basidiomycota of Victoria State, Australia. 8-9. Additional taxa, collecting, ecology and taxonomy. Kew Bulletin 40: 827-842.

Bougher, N.L. \& Castellano, M.A. 1993. Delimitation of Hymenogaster sensu stricto and four new segregated genera. Mycologia 85: 273-293.

Castellano, M.A., Trappe, J.M. \& Luoma, D.L. 2004. Sequestrate fungi. In: G.M. Mueller, G.F. Bills \& M.S. Foster (eds.). Biodiversity of Fungi: inventory and monitoring methods. Elsevier, Burlington, pp. 197-213.

Dodge, C.W. \& Zeller, S.M. 1934. Hymenogaster and related genera. Annals of the Missouri Botanical Garden 21: 625-708.

Francis, A.A. \& Bougher, N.L. 2002. Historical and current perspectives in the systematics of Australian cortinarioid sequestrate (truffle-like) fungi. Australasian Mycologist 21: 81-93.

Francis, A.A. \& Bougher, N.L. 2004. Cortinarioid sequestrate (truffle-like) fungi of Western Australia. Australasian Mycologist 23: 1-26.

Giachini, A.J., Oliveira, V.L., Castellano, M.A. \& Trappe, J.M. 2000. Ectomycorrhizal fungi in Eucalyptus and Pinus plantations in southern Brazil. Mycologia 92: 1166-1177.

Kirk, P.M., Cannon, P.F., David, J.C. \& Stalpers, J.A. 2001. Ainsworth \& Bisby's Dictionary of the Fungi. 9ed. CABI/IMI, Wallingford.

Kornerup, A. \& Wanscher, J.H. 1978. Methuen handbook of colour. 3 ed. Eyre Methuen, London.

Lago, M., Bougher, N.L. \& Castro, M.L. 2001. Morphological variability and implication for definition of taxa in the Descolea-Setchelliogaster-Descomyces complex. Mycotaxon 78: 37-57.

Lago, M. \& Castro, M.L. 2004. Macrobasidiomicetos asociados a Eucalyptus en la Península Ibérica. Fungi non Delineati 27: 1-84.
Lazo, W. 1972. Fungi from Chile I. Some gasteromycetes and Agaricales. Mycologia 64: 786-798.

Martín, M.P. \& Moreno, G. 2001. Molecular data confirm Setchelliogaster tenuipes and S. rheophyllus as Cortinariales. Mycotaxon 78: 257-263.

Matheny, P.B., Curtis, J.M., Hofstetter, V., Aime, M.C., Moncalvo, J.-M., Ge, Z.-W., Yang, Z.-L., Slot, J.C., Ammirati Junior, J.F., Baroni, T.J., Bougher, N.L., Hughes, K.W., Lodge, D.L., Kerrigan, R., Seidl, M.T., Aanen, D.K., Denitis, M., Daniele, G.M., Desjardin, D.E., Kropp, B.R., Norvell, L.L., Parker, A., Vellinga, E.C., Vilgalys, R. \& Hibbett, D.S. 2006. Major clades of Agaricales: a multilocus phylogenetic overview. Mycologia 98: 982-995.

Moreno, G., Kreisel, H. \& Galán, R. 1997. Setchelliogaster rheophyllus comb. nova (Bolbitiaceae, Agaricales) an Iberic and North African fungus species. Feddes Repertorium 108: 567-573.

Miller Junior, O.K. \& Miller, H.H. 1988. Gasteromycetes: morphological and development features with keys to the orders, families, and genera. Mad River, Eureka.

Pegler, D.N. 1983. Agaric Flora of the Lesser Antilles. Kew Bulletin Additional Series 9: 1-668.

Pegler, D.N., Spooner, B.M. \& Young, T.W.K. 1993. British truffles: a revision of British hypogeous fungi. Royal Botanic Gardens, Kew.

Peintner, U., Bougher, N.L., Castellano, M.A., Moncalvo, J.M., Moser, M.M., Trappe, J.M. \& Vilgalys, R. 2001. Multiple origins of sequestrate fungi related to Cortinarius (Cortinariaceae). American Journal of Botany 88: 2168-2179.

Rick, J. 1934. Himenogastrineas Riograndenses. Egatea 19: $110-112$.

Rick, J. 1961. Basidiomycetes Eubasidii in Rio Grande do Sul - Brasilia. 6. Iheringia, Série Botânica 9: 451480.

Singer R. 1986. The Agaricales in modern taxonomy. 4 ed. Koeltz, Koenigstein.

Smith, A.H. 1973. Agaricales and related gasteromycetes. In: G.C. Ainsworth, F.K. Sparrow \& A.S. Sussman (eds.). The Fungi: an advanced treatise. v. IVB. Academic Press, New York, pp. 421-450.

Thiers, H.D. 1984. The secotioid syndrome. Mycologia 76: $1-8$.

Wright, J.E. 1980. El género Setchelliogaster en Buenos Aires (Secotiaceae, Gasteromycetes). Boletín de la Sociedad Argentina de Botánica 19: 237-241.

Wright, J.E. \& Albertó, E. 2006. Guía de hongos de la región pampeana. v. II. Hongos sin laminillas. L.O.L.A., Buenos Aires. 